\title{
STUDI TENTANG PELAKSANAAN HAK INISIATIF DPRD KUTAI KARTANEGARA PERIODE 2014-2018
}

\author{
Efri Novianto $^{1}$ dan Salehuddin ${ }^{2}$ \\ ${ }^{1}$ Universitas Kutai Kartanegara dan ${ }^{2}$ DPRD Kutai Kartanegara, Indonesia \\ efrinovianto@unikarta.ac.id
}

\begin{abstract}
One of the important functions of the DPRD is the formation of regional regulations together. For the implementation of this function, the DPRD was given the right of initiative to submit a draft Regional Regulation. The purpose of this research is to find out and analyze the role of the Regional Representative Council of Kutai Kartanegara in carrying out the function of forming Regional Regulations, specifically related to the implementation of DPRD initiative rights, supporting and inhibiting factors. This study uses a descriptive qualitative approach with interactive data analysis tools. From the results of the study, the implementation of the DPRD Kutai Kartanegara initiative rights for the period 2014-2018 has been carried out properly, but it is not optimal because on average only 8,05\% has been approved as a Regional Regulation. In theory, the factors that influence the implementation of DPRD initiative rights are education, experience and data/ information factors, but this has been overcome with the existence of Expert Team/ Expert Groups, workshops or training to increase the capacity of the DPRD and Academic Manuscripts in each Regional Regulation Design submitted to the DPRD, so that it is no longer a obstacle factor. The obstacles to the implementation of the DPRD's role are more due to political factors, budget support, and consistency of regulations.
\end{abstract}

Keywords: DPRD, Function of Forming Regional Regulations, and Initiative Rights

\begin{abstract}
Abstrak
Salah satu fungsi penting DPRD adalah pembentukan peraturan daerah. DPRD diberikan hak inisiatif untuk mengajukan rancangan Peraturan Daerah. Tujuan Penelitian ini adalah untuk mengetahui dan menganalisis peran DPRD Kutai Kartanegara dalam melaksanakan fungsi pembentukan Peraturan Daerah, khususnya terkait dengan pelaksanaan hak inisiatif DPRD, faktor pendukung dan penghambat. Penelitian ini menggunakan pendekatan kualitatif deskriftif dengan alat analisis data interaktif. Dari hasil penelitian, pelaksanaan hak inisiatif DPRD Kutai Kartanegara periode 2014-2018 telah dilaksanakan dengan baik, hanya saja tidak optimal karena rata-rata hanya 8,05\% yang disahkan menjadi Peraturan Daerah. Secara teori faktor yang mempengaruhi pelaksanaan hak inisiatif DPRD tersebut adalah faktor pendidikan, pengalaman dan faktor data/ informasi akan tetapi hal ini telah di tanggulangi dengan adanya Tim Ahli/ Kelompok Pakar, adanya workshop atau pelatihan untuk meningkatkan kapasitas DPRD dan adanya Naskah Akademik dalam setiap Rancangan Peraturan Daerah yang diajukan ke DPRD, sehingga tidak lagi menjadi faktor penghambat. Hambatan pelaksanaan peran DPRD lebih disebabkan oleh faktor politis, dukungan anggaran dan konsistensi regulasi.
\end{abstract}

Kata Kunci: DPRD, Fungsi Pembentukan Perda, dan Hak Inisiatif

Diterima 30 November 2018; Diterima dengan revisi 5 Maret 2019; Dipublikasikan 1 Mei 2019

2406-9515 (p) / 2528-441X (e)

(C) 2019. Efri Novianto \& Salehuddin. Dipublikasikan oleh JAP FIS UNY 


\section{PENDAHULUAN}

Otonomi Daerah memberikan ruang bagi daerah untuk mengatur dan mengurus rumah tangganya sendiri dalam kerangka Negara Kesatuan Republik Indonesia (NKRI). Berbeda dengan konsep negera federal, otonomi daerah mensyaratkan adanya pelimpahan kewenangan dari pemerintah pusat kepada pemerintah daerah. Di Indonesia sendiri, otonomi daerah terletak pada pemerintah Kabupaten atau Kota (Desentralisasi), sedangkan pemerintah propinsi adalah perpanjangan tangan pemerintah pusat di daerah (Dekonsentrasi).

Undang-Undang Nomor 23 Tahun 2014 menyebutkan bahwa Pemerintahan Daerah adalah penyelenggaraan urusan pemerintahan oleh pemerintah daerah dan dewan perwakilan rakyat daerah menurut asas otonomi dan tugas pembantuan dengan prinsip otonomi luas dalam bingkai Negara Kesatuan Republik Indonesia. Selanjutnya dalam ketentuan umum Undang-Undang Nomor 23 Tahun 2014 disebutkan bahwa pemerintah daerah adalah Kepala Daerah sebagai unsur penyelenggara pemerintahan daerah yang memimpin pelaksanaan urusan pemerintahan yang menjadi kewenangan daerah otonom. Sedangkan
Dewan Perwakilan Rakyat Daerah (DPRD) adalah badan perwakilan rakyat tingkat daerah sebagai salah satu unsur penyelenggara pemerintahan daerah. Dari penjelasan tersebut, bisa dipahami bahwa Kepala Daerah dan DPRD adalah unsur penyelenggara Pemerintahan Daerah yang memiliki kedudukan seimbang (checks and balances).

DPRD sendiri memiliki tiga fungsi utama yaitu fungsi pembentukan peraturan daerah, fungsi anggaran dan fungsi pengawasan. Sebagai unsur penyelenggara Pemerintahan Daerah, Kepala Daerah dan DPRD membahas dan mengesahkan anggaran dan peraturan daerah secara besama-sama. Hal ini merupakan praktek dari pelaksanaan checks and balances antara DPRD dan Kepala Daerah. Sedangkan untuk pengawasan, DPRD yang memiliki fungsi dominan untuk mengawasi pemerintah daerah karena pada dasarnya pemerintah daerah yang melaksanakan anggaran dan peraturan daerah yang telah ditetapkan (eksekutif).

Untuk melaksanakan fungsi, tugas dan wewenang pembentukan peraturan daerah (Perda), DPRD membentuk Badan Pembentukan Peraturan Daerah 
(Bapemperda) yang merupakan salah satu alat kelengkapan DPRD. Bapemperda bertugas untuk menyusun rancangan program pembentukan perda, berkoordinasi untuk penyusunan program pembentukan perda antara DPRD dan pemerintah daerah, menyiapkan rancangan perda usul DPRD dan memberikan pertimbangan terhadap rancangan perda yang diajukan oleh anggota, komisi dan/atau gabungan komisi, di luar prioritas rancangan perda tahun berjalan atau di luar rancangan perda yang terdaftar dalam program pembentukan perda.

Proses pembahasan rancangan perda terdiri dari dua tahapan pembicaraan yang pembicaraan tingkat 1 dan pembicaraan tingkat 2. Pembicaraan tingkat 1 adalah pembicaraan awal sebelum sebuah rancangan perda disepakati untuk dibahas lebih lanjut oleh DPRD. Sedangkan pembicaraan tingkat 2 adalah tindak lanjut hasil kesepakatan pada pembicaraan tingkat 1 yaitu pembahasan rancangan perda lebih lanjut sampai dengan pengambilan keputusan untuk pengesahan rancangan perda menjadi perda. Dalam pembicaran tingkat 1, wewenang tersebut melekat pada Bapemperda, sedangkan pada pembicaraan tingkat 2 , DPRD dapat menugaskan Komisi, Komisi Gabungan atau membentuk Panitia Khusus untuk membahas lebih lanjut rancangan perda. Selanjutnya Komisi, Komisi Gabungan atau Panitia Khusus menyampaikan laporan hasil pembicaraan tingkat 2 tersebut dalam sidang paripurna untuk mengambilan keputusan pengesahan rancangan perda menjadi perda. Tugas DPRD dalam pembentukan perda dianggap telah selesai sampai pada tahapan pengesahan, selanjutnya pengundangan dan pencatatan pada lembaran daerah merupakan kewenangan Kepala Daerah melalui Sekretaris Daerah.

Dalam pelaksanaan fungsi, tugas dan wewenang pembentukan perda, DPRD Kabupaten Kutai Kartanegara dirasa belum optimal. Sejak tahun 2014, dari 149 Raperda yang masuk, hanya 82 Raperda yang disahkan menjadi Perda $(55,03 \%)$ dimana hanya 12 Raperda yang berasal dari pelaksanaan hak inisiatif DPRD (8,05\%). Atas dasar hal tersebut dapat disimpulkan bahwa kinerja DPRD Kabupaten Kutai Kartanegara dalam hal pembentukan peraturan daerah masih sangat rendah. Peneliti melihat ada permasalahan pada peran DPRD Kabupaten Kutai 
Kartanegara dalam pelaksanaan fungsi pembentukan peraturan daerah khususnya yang berkaitan dengan pelaksanaan hak inisiatif DPRD periode 2014-2018. Seharusnya peraturan daerah yang disyahkan dan berasal dari pelaksanaan hak inisiatif DPRD lebih dominan, karena pembentukan peraturan daerah merupakan salah satu fungsi yang melekat pada kelembagaan DPRD.

Kurang optimalnya kinerja DPRD dalam pelaksanaan pembentukan peraturan daerah juga terjadi di daerah lain. Hasil kajian Jusmiati menemukan bahwa pelaksanaan fungsi legislasi DPRD Kabupaten Kutai Timur tidak berjalan secara optimal, dilihat dari peraturan daerah yang ada sejak tahun 2009-2012 tidak ada satupun peraturan daerah yang berasal dari inisiatif DPRD; semua peraturan daerah yang ada justru diprakarsai oleh pemerintah daerah dan tidak ada penentuan berapa jumlah perda yang harus dihasilkan dalam waktu tertentu (Jusmiati, Tahun 2013 Nomor 1 Volume 5). Hasil kajian Toni Kurniadi mengungkapkan hal yang sama dimana ditemukan bahwa pelaksanaan fungsi legislasi DPRD Provinsi Kalimantan Barat dalam penyusunan Raperda belum sesuai dengan harapan dimana perda yang dihasilkan belum sepenuhnya mewakili berbagai tuntutan/aspirasi masyarakat, Raperda yang dihasilkan DPRD relatif masih rendah, yakni banyak Perda selama kurun waktu tertentu tidak mencapai target, bahkan terjadi penurunan dari tahun ke tahun. Raperda yang dihasilkan, pada umumnya sebagian besar lebih mencerminkan produk pemerintah dari pada keinginan masyarakat, kondisi demikian menunjukkan bahwa fungsi ideal dari DPRD Provinsi Kalimantan Barat untuk menyerap dan memproses aspirasi masyarakatnya belum berfungsi secara optimal (Kurniadi, 2013). Penelitian ini ditujukan untuk selain menguji teori yang perna ada juga mengalisis faktor lainnya yang mempengarui kinerja DPRD Kutai Kartanegara dalam pelaksanaan fungsi pembentukan perda khususnya yang berkaitan dengan pelaksanaan hak inisiatif DPRD.

Pembentukan peraturan daerah sesungguhnya merupakan salah satu dimensi strategis administrasi publik (dimensi kebijakan). Keban menyebutkan bahwa dimensi kebijakan menyangkut proses pembuatan keputusan untuk menentukan tujuan dan cara alternatif terbaik untuk mencapai 
tujuan tersebut (Keban, 2015). Kebijakan sendiri menurut Thomas $\mathrm{R}$ Dye (Abidin, 2006) merupakan pilihan pemerintah untuk melakukan atau tidak melakukan sesuatu. Suharto mengatakan bahwa kebijakan publik adalah keputusan-keputusan atau pilihan-pilihan tindakan yang bersifat strategis, oleh karenanya kebijakan publik haruslah dibuat oleh mereka yang memegang otoritas politik yaitu mereka yang menerima mandat dari publik atau orang banyak, umumnya melalui proses pemilihan umum (pemilu) yang bertindak atas nama dan mewakili kepentingan rakyat (Suharto, 2009)

Charles Lindblom membagi prosesproses penyusunan kebijakan publik kedalam beberapa tahap yaitu punyusunan agenda, formulasi kebijakan, adopsi kebijakan, implementasi kebijakan dan evaluasi kebijakan. Pada tahap penyusunan agenda, pembuat kebijakan menempatkan masalah-masalah publik dalam agenda publik untuk kemudian dipilih dan ditempatkan dalam agenda kebijakan. Selanjutnya masalah yang telah masuk dalam agenda kebijakan kemudian dibahas oleh para pembuat kebijakan. Masalah-masalah tersebut di identifikasi untuk kemudian dicari pemecahan masalah terbaik. Pemecahan masalah tersebut berasal dari berbagai alternatif yang telah ada. Masingmasing aktor akan mengusulkan alternative pemecahan masalah terbaik. Dari sekian banyak alternatif kebijakan yang ditawarkan oleh perumus kebijakan, pada akhirnya sala satu alternatif kebijakan tersebut diadopsi dengan dukungan mayoritas legislatif, konsensus antara direktur lembaga atau keputusan peradilan. Selanjutnya alternatif kebijakan yang telah dipilih diimplementasikan oleh badan-badan administratif maupun agen-agen pemerintah ditingkat bawah dan pada akhirnya akan dilakukan evaluasi untuk melihat sejauhmana kebijakan yang telah dibuat mampu memecahkan masalah (Winarno, 2007).

Proses perumusan dan aplikasi kebijakan seringkali timbul kontroversi dalam masyarakat. Hal ini sebagai akibat dari perbedaan kepentingan antar kelompok, perbedaan prioritas dari tujuan yang akan dicapai, sekalipun diantara kelompok tersebut memiliki kepentingan yang sama dan perbedaan pengertian tentang rumusan masalah. Diantara masalah-masalah publik, terdapat perbedaan kualitas, wawasan 
dan keterkaitan. Oleh karena itu, masalah tersebut perlu dikelompokan kedalam masalah strategis yang dilihat dari luas cakupannya, jangka waktunya, keterkaitanya dan resiko atau keuntungan yang ditimbulkan (Abidin, 2006).

Dalam melaksanakan fungsi pembentukan perda, idealnya anggota DPRD bertindak dan berperilaku sebagai representasi masyarakat. Keberhasilan DPRD untuk menegakkan keserasian antara kepentingan anggota masyarakat yang diwakilinya dengan kepentingan berbagai kelompok dan lembaga harus memperhatikan empat faktor (Sanit, 2012), yakni :

1. Integritas dan kemampuan atau keterampilan anggota badan legislatif.

2. Pola hubungan anggota badan tersebut dengan anggota masyarakat yang mereka wakili yang tercermin di dalam sistem perwakilan yang berlaku.

3. Struktur organisasi badan legislatif yang merupakan kerangka formal bagi kegiatan anggota dalam bertindak sebagai wakil rakyat.

4. Hubungan yang tercermin dalam pengaruh timbal balik antara badan legislatifdengan eksekutif dan lembaga-lembaga lainnya sebagai unit-unit pemerintahan ditingkat daerah, serta hubungan badan tersebut dengan lembaga-lembaga yang sama di tingkat yang lebih tinggi hierarkinya.

Peranan anggota DPRD dalam rangka melaksakan tugas dan fungsinya untuk pencapaian satu tujuan dalam rangka membahas dan memberikan persetujuan rancangan perda, akan sangat dipengaruhi oleh banyak faktor yang berbeda antara yang satu dengan yang lainnya, tergantung dari sifat dan bidang kegiatan atau usaha dalam melaksanakan peranannya. Ada tiga faktor yang mempengaruhi belum terlaksananya peranan suatu organisasi dalam melaksanakan tugas dan fungsinya (Prawirosentono, 2002) yaitu:

1. faktor pendidikan (kemampuan aparat);

2. faktor data/ informasi;

3. faktor pengalaman.

METODE

Penelitian ini menggunakan pendekatan kualitatif dengan motode deskriftif. Fokus dalam penelitian adalah peran DPRD dalam pembentukan peraturan daerah mulai 
dari menerima usulan raperda, menyusun program pembentukan perda, pembicaraan tingkat 1 dan tingkat 2 DPRD dengan Pemerintah Daerah dan pengesahan raperda menjadi perda. Selanjutnya faktor pendukung dan penghambat yang dilihat dari sumber daya manusia (pendidikan), pengalaman, dukungan data dan informasi.

Sumber data dalam penelitian ini terdiri dari dua yaitu data primer yang diperoleh secara langsung dari obyek penelitian atau key informan yang dijaring melalui wawancara mendalam (in-dept Interview) dengan Pimpinan dan Anggota DPRD, Sekretaris Dewan, Staf Bagian Perundang-Undangan, Tim Ahli/ Kelompok Pakar dan Akademisi yang perna terlibat dalam penyusunan Naskah Akademik raperda. Sedangkan data sekunder diperoleh dari data dokumentasi dan arsip Sekretariat DPRD Kabupaten Kutai Kartanegara, peraturan perundang-undangan dan dokumen lain yang mendukung penelitian.

\section{HASIL DAN PEMBAHASAN}

Dasar hukum pembentukan perda terdiri atas Undang-Undang Nomor 23 Tahun 2014 tentang Pemerintahan
Daerah, Peraturan Pemerintah Nomor 12 Tahun 2018 tentang Pedoman Penyusunan Peraturan Tata Tertib DPRD, Peraturan Menteri Dalam Negeri Nomor 80 Tahun 2015 tentang Pembentukan Produk Hukum Daerah dan Peraturan DPRD Nomor 1 Tahun 2018 tentang Tata Tertib. Peraturan perundang-undangan inilah yang kemudian dijadikan pedoman bagi DPRD Kutai Kartanegara dalam pembentukan perda.

Tahap awal pembentukan perda adalah penyusunan program pembentukan perda (propemperda). Propemperda disusun sebelum memasuki tahun anggaran berikutnya. Kewenangan penyusunan propemperda berada di Badan Pembentukan Peraturan Daerah (Bapemperda). Propemperda memuat daftar urutan dan prioritas rancangan perda beserta alasannya untuk setiap tahun anggaran. Propemperda disusun secara terencana, terpadu dan sistematis. Propemperda inilah yang nantinya dijadikan pedoman dalam penyampaian usulan pembentukan perda baik yang berasal dari DPRD maupun dari Kepala Daerah (Bupati).

Sebelum rencana program pembentukan perda tersebut diajukan 
dalam rapat paripurna untuk disetujui oleh DPRD dan Bupati, terlebih dahulu dilakukan rapat koordinasi antara Bagian Hukum Sekretariat Daerah dengan Bapemperda. Rapat koordinasi ini ditujukan untuk menyusun urutan dan prioritas rancangan perda yang akan dibahas pada tahun anggaran berikutnya. Acuan penyusunan program pembentukan perda adalah Permendagri 80 Tahun 2015 dan Peraturan DPRD Nomor 1 Tahun 2018. Penyusunan program pembentukan perda didasarkan pada perintah peraturan perundangundangan yang lebih tinggi, rencana pembangunan daerah, penyelenggaran otonomi daerah dan tugas pembantuan, dan aspirasi masyarakat daerah.

Tahapan penyusunan program pembentukan perda diawali dari Bapemperda bersurat kepada KomisiKomisi DPRD untuk menyampaikan dan mengusulkan rancangan perda hasil tindak lanjut rapat dengar pendapat atau aspirasi masyarakat. Sementara untuk usulan Kepala Daerah, Bapemperda melalui pimpinan DPRD bersurat kepada Bupati untuk menyampaikan rancangan perda prioritas yang akan dibahas pada tahun anggaran berikutnya. Setelah usulan judul rancangan perda baik dari Komisi
DPRD dan Kepala Daerah tersebut diterima, maka selanjutnya Bapemperda berkoordinasi dengan Bagian Hukum Sekretariat Daerah dibantu oleh Tim Ahli melakukan verifikasi kelengkapan dokumen pendukung, harmonisasi dan pembulatan materi pembahasan sesuai dengan ketentuan peraturan perundangundangan yang berlaku.

Muatan dalam perda harus menggambarkan asas pengayoman, asas kemanusiaan, asas kebangsaan, asas kekeluargaan, asas kenusantaraan, asas bhineka tunggal ika, asas keadilan, asas kesamaan kedudukan dalam hukum, asas pemerintahan, asas ketertiban, asas kepastian hukum, asas keseimbangan, asas keserasian dan asas keselarasan. Hasil koordinasi dan kesepakatan antara Bapemperda dan Bagian Hukum Sekretariat Daerah disampaikan pada rapat paripurna untuk disetujui bersama menjadi Propemperda tahun anggaran berikutnya.

Meskipun propemperda merupakan pedoman dalam penyampaian usulan rancangan perda, DPRD maupun Bupati dapat mengajukan rancangan perda diluar propemperda yang telah disepakati, selama memenuhi syarat sebagaimana yang digariskan didalam Peraturan Menteri Dalam Negeri Nomor 
80 Tahun 2015. Syarat untuk dapat mengajukan rancangan perda diluar propemperda diantaranya adalah:

1. Untuk menanggulangi keadaan luar biasa, keadaan konflik atau bencana alam;

2. Menindaklanjuti kerjasama dengan fihak lain;

3. Mengatasi keadaan tertentu lainnya yang memastikan adanya urgensi atas suatu rancangan perda yang dapat disetujui bersama oleh bapemperda dan bagian hukum sekretariat daerah;

4. Akibat pembatalan oleh Gubernur sebagai wakil pemerintah pusat; dan

5. Adanya perintah dari peraturan perundang-undangan yang lebih tinggi setelah propemperda ditetapkan.

Selain itu juga, didalam Propemperda, dapat dimasukan daftar kumulatif terbuka yang terdiri atas akibat putusan Mahkamah Agung dan APBD. Penetapan skala prioritas dalam Propemperda didasarkan atas perintah peraturan perundang-undangan yang lebih tinggi, rencana pembangunan daerah, penyelenggeran otonomi daerah dan tugas pembantuan serta adanya aspirasi masyarakat di daerah.
Adanya ketentuan yang membolehkan pengajuan rancangan perda diluar Propemperda ini membuka ruang bagi DPRD maupun Bupati untuk mengajukan rancangan perda baru diluar yang telah disepakati. Akan tetapi disisi yang lain membuat penetapan Propemperda menjadi sia-sia, karena pada saat tertentu dengan alasan seperti yang disebutkan dalam Permendagri 80 Tahun 2015, DPRD maupun Bupati dapat menyampaikan rancangan perda diluar propemperda yang telah disepakti. Padahal penyusunan propemperda melalui proses rapat koordinasi yang panjang antara Bagian Hukum Sekretariat Daerah dengan Bapemperda, sampai kemudian disepakati bersama antara DPRD dan Bupati pada rapat paripurna. Terlepas dari hal tersebut, Propemperda tetaplah merupakan pedoman bagi DPRD maupun Bupati dalam mengajukan usulan rancangan perda.

Selanjutnya adalah penyampaian usulan rancangan perda. Pada dasarnya rancangan perda dapat berasal dari DPRD maupun Bupati sebagai Kepala Daerah. Setiap rancangan perda yang diajukan harus disertai penjelasan dan/atau naskah akademik. Naskah akademik ini merupakan hasil 
penelitian atau pengkajian hukum terhadap suatu masalah tertentu yang dapat dipertanggungjawabkan secara ilmiah mengenai pengaturan masalah tersebut dalam rancangan perda, sebagai solusi terhadap permasalahan dan memenuhi kebutuhan hukum masyarakat. Naskah Akademik merupakan hasil analisis kebijakan yang nantinya merekomendasikan perlu tidaknya dibuat sebuah perda. Naskah akademik dibuat oleh analis kebijakan, baik yang berasal dari akademisi atau perguruan tinggi maupun kelompok profesional lainnya.

Pada DPRD Kabupaten Kutai Kartanegara, penyusunan Naskah Akademik atas rancangan perda yang berasal dari hak inisiatif atau usul DPRD, difasilitasi oleh Sekretariat DPRD yang bekerjasama dengan perguruan tinggi dan professional lainnya. Tata cara penyampaian usulan rancangan perda pada DPRD Kutai Kartanegara secara teknis telah diatur dalam Standar Operasional Prosedur (SOP). Di dalam SOP penyampaian usulan rancangan perda diatur mekanisme pengajuan, kelengkapan dokumen dan penanggung jawab.

Tim Ahli/ Kelompok Pakar yang bertugas untuk memverifikasi kelengkapan administrasi untuk selanjutnya disampaikan dalam rapat internal Bapemperda. Dari rapat internal inilah kemudian direkomendasikan kepada pimpinan DPRD untuk diajukan dalam rapat paripurna DPRD. Jika paripurna DPRD menyetujui usulan rancangan perda tersebut, maka akan dibentuk panitia khusus atau komisi yang akan bertugas membahas lebih lanjut dan menyempurnakan rancangan perda tersebut.

Secara umum pembahasan rancangan perda terdiri dari dua tingkat pembicaraan yaitu pembicaraan tingkat I dan tingkat II. Dalam pembicaraan tingkat I, Bupati menjelaskan dalam rapat paripurna mengenai rancangan perda yang mereka ajukan, kemudian dilanjutkan dengan pemandangan umum fraksi dan tanggapan atau jawaban Bupati terhadap pemandangan umum fraksi tersebut. Jika mayoritas fraksi di DPRD menyetujui rancangan perda untuk dibahas lebih lanjut, maka paripurna DPRD akan melakukan pembentukan Panitia Khusus. Dalam hal usul rancangan perda berasal dari DPRD, maka alat kelengkapan DPRD yang akan menyampaikan penjelasan dalam rapat paripurna, sedangkan Bupati akan memberikan tanggapan, 
baru kemudian dibentuk Panitia Khusus.

Panitia Khusus merupakan alat kelengkapan DPRD yang bersifat sementara, dibentuk sesuai dengan kebutuhan untuk melaksanakan tugastugas tertentu. Keanggotaan Pansus terdiri dari anggota DPRD dari masingmasing perwakilan fraksi yang ditetapkan secara proporsional. Anggota pansus sendiri ditetapkan paling banyak 11 orang yang bertugas melakukan pembahasan rancangan perda dengan masa kerja paling lama 3 bulan dan dapat diperpanjang jika diperlukan. Pimpinan pansus dipilih oleh anggota pansusnya masing-masing, hanya saja karena mayoritas keanggotaan berasal dari Fraksi Golkar, maka hampir setiap pansus dipimpin oleh anggota DPRD dari Fraksi Golkar.

Sedangkan pembicaraan tingkat II merupakan tahapan dalam pengambilan keputusan yang terdiri dari penyampaian laporan pansus yang berisikan proses pembahasan rancangan perda, pendapat fraksi-fraksi DPRD dan hasil pembahasan antara pansus dengan perwakilan dari pemerintah daerah yang ditugaskan oleh Bupati. Pansus apabila diperlukan dapat melakukan kunjungan kerja dalam rangka studi banding ke daerah lainnya, dan melakukan konsultasi ke pemerintah propinsi atau kementerian terkait.

Tahap selanjutnya pansus menyampaikan laporan hasil pembahasan dalam rapat paripurna. Dalam laporan pansus tersebut dimuat hasil pembahasan rancangan perda dan pendapat akhir fraksi. Setelah laporan disampaikan, maka pimpinan DPRD menawarkan kepada anggota DPRD terkait dengan persetujuan terhadap rancangan perda menjadi perda tersebut yang dilanjutkan dengan penyampaian pendapat akhir Bupati untuk selanjutnya dilakukan penanda-tanganan persetujuan bersama antara DPRD dan Bupati. Persetujuan bersama tersebut merupakan bentuk pengesahan rancangan perda menjadi perda.

Dalam hal persetujuan rancangan perda menjadi perda, kehadiran anggota harus memenuhi kuorum yaitu minimal dihadiri oleh $2 / 3$ anggota dari 45 anggota DPRD Kutai Kartanegara atau minimal 30 orang anggota. Persetujuan pengesahan rancangan perda menjadi perda minimal disetujui $1 / 2$ anggota DPRD yang hadir pada saat paripurna dilakukan. Hal tersebut secara jelas diatur dalam Peraturan DPRD Nomor 1 Tahun 2018. Terkadang kehadiran 
anggota DPRD tidak memenuhi kuorum sehingga harus mengalami penundaan dikarenakan alasan teknis dan politis. Alasan teknis disini adalah karena masih dalam perjalanan menuju gedung DPRD atau alasan politis karena belum ditemukan titik temu atau kesepakatan dari masing-masing Fraksi DPRD dengan Pemerintah Daerah.

Tidak semua rancangan perda yang diajukan berlanjut kepembicaraan tingkat II. Hal ini dimungkinkan karena alasan tertentu, rancangan perda yang diajukan ditolak oleh mayoritas anggota fraksi DPRD atau ditarik kembali oleh Bupati. Dalam hal rancangan perda yang diajukan ditarik kembali, maka Bupati harus menyampaikan penjelasan alasan penarikan rancangan perda yang diajukan. Hanya saja selama periode 2014 sampai dengan saat ini belum ada rancangan perda yang diajukan, ditarik kembali oleh Bupati, akan tetapi ada beberapa rancangan perda yang dikembalikan ke Pemerintah Daerah karena tidak memenuhi syarat atau tidak bisa disahkan karena bertentangan dengan peraturan perundang-undangan yang lebih tinggi diantaranya Raperda tentang Kepemudaan, Raperda tentang Ekonomi Kreatif, Raperda tentang Perubahan RTRW dan Raperda tentang
Pembentukan PT. Mahakam Gerbang Raja Migas.

Rancangan perda yang telah disetujui bersama, selanjutnya disampaikan kepada Bupati untuk dilakukan pengundangan. Sebelum rancangan perda tersebut di undangkan atau dicatat dalam lembaran daerah, sesuai dengan ketentuan Permendagri 80 Tahun 2015 Pasal 100 ayat (2) harus mendapat nomor register dari Biro Hukum Propinsi melalui proses evaluasi. Setelah mendapatkan nomor register, Bupati menandatangani perda tersebut, selanjutnya diundangkan dalam lembaran daerah. Apabila Bupati menolak menandatangani perda yang telah mendapatkan nomor register, tiga puluh hari setelah mendapatkan nomor register dianggap sah dan wajib diundangkan dalam lembaran daerah.

Adanya kewajiban untuk mendapatkan nomor register dari pemerintah propinsi ini menyebabkan peran DPRD dalam pembentukan peraturan daerah menjadi mandul, karena realita yang terjadi banyak perda yang telah disahkan tidak dapat diundangkan dengan alasan belum selesai dilakukan evaluasi atau belum mendapatkan nomor register dari Biro Hukum Propinsi. Permendagri 80 
Tahun 2015 tidak mengatur secara jelas berapa lama proses evaluasi untuk mendapatkan nomor register itu dilakukan oleh Biro Hukum Propinsi, sehingga Bupati dan DPRD hanya bisa menunggu hasil evaluasi karena perda tetap tidak bisa di undangkan dalam lembaran daerah jika tidak mendapat nomor register.

Dari empat peran DPRD dalam melaksanakan fungsi pembentukan perda mulai dari menyusun propemperda, menerima usulan rancangan perda, pembicaraan tingkat 1 dan tingkat 2 DPRD dengan Pemerintah Daerah sampai dengan pengesahan rancangan perda menjadi perda telah dilaksanakan dengan baik, meskipun rata-rata hanya sekitar 55,03\% raperda dalam propemperda yang disahkan menjadi perda. Berdasarkan hal tersebut, dapat disimpulkan bahwa DPRD Kutai Kartanegara berperan dalam melaksanakan fungsi pembentukan perda, meskipun kurang optimal. Sedangkan terkait dengan pelaksanaan hak inisiatif DPRD periode 2014-2018, dapat disimpulkan bahwa hak inisiatif ini telah dilaksanakan dengan baik, meskipun pelaksanaan peran tersebut juga tidak optimal karena hanya $8,05 \%$ perda yang berasal dari hak inisiatif DPRD yang disahkan menjadi perda.

Tabel 3. Daftar Raperda yang disahkan menjadi Perda

\begin{tabular}{|c|c|c|c|c|c|}
\hline Tahun & $\begin{array}{c}\text { Jumlah } \\
\text { Propemperda }\end{array}$ & Perda disahkan & $\%$ & $\begin{array}{c}\text { Dari hak } \\
\text { inisiatif }\end{array}$ & $\%$ \\
\hline 2014 & 33 Raperda & 16 Perda & $48,48 \%$ & 1 Perda & $3,03 \%$ \\
\hline 2015 & 33 Raperda & 24 Perda & $72,73 \%$ & 3 Perda & $9,09 \%$ \\
\hline 2016 & 31 Raperda & 17 Perda & $54,84 \%$ & 2 Perda & $6,45 \%$ \\
\hline 2017 & 24 Raperda & 11 Perda & $45,83 \%$ & 4 Perda & $16,66 \%$ \\
\hline 2018 & 28 Raperda & 14 Perda & $50,00 \%$ & 2 Perda & $7,14 \%$ \\
\hline Jumlah & 149 Raperda & 82 Perda & $\mathbf{5 5 , 0 3 \%}$ & 12 Perda & $\mathbf{8 , 0 5 \%}$ \\
\hline
\end{tabular}

Sumber: Bapemperda DPRD Kutai Kartanegara Tahun 2019

Jika melihat tabel diatas, kinerja DPRD Kabupaten Kutai Kartanegara dalam pembentukan Perda mengalami fluktuasi dengan kecenderungan menurun. Rencana pengesahan Perda yang telah disusun dalam Propemperda tidak perna tercapai $100 \%$, bahkan dalam periode 2015 sampai dengan 2017 terus mengalami penurunan dan kembali naik tahun 2018. 


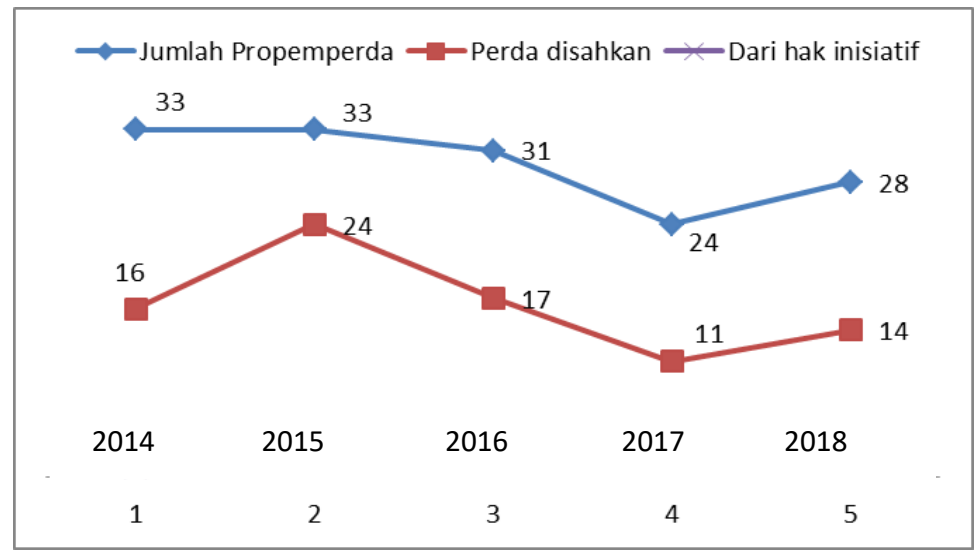

Gambar 1. Kinerja Pembentukan Perda

Sumber: diolah dari hasil penelitian

Tabel 4. Perda dari Inisiatif DPRD tahun 2014-2018

\begin{tabular}{|r|l|c|}
\hline No & \multicolumn{1}{|c|}{ Nama Peraturan Daerah } & Tahun \\
\hline 1 & Penyelenggaraan Praktek Keperawatan & 2014 \\
\hline 2 & Bangunan Gedung Pelaku Olahraga & 2015 \\
\hline 3 & $\begin{array}{l}\text { Kemitraan Pelaku Usaha Dengan } \\
\text { Profesional }\end{array}$ & 2015 \\
\hline 4 & Pelestarian Adat Istiadat Dan Budaya & 2016 \\
\hline 5 & Pengembangan Kewirausahaan Pemuda & 2016 \\
\hline 6 & Pengarus Utamaan Gender & 2017 \\
\hline 7 & $\begin{array}{l}\text { Izin Membuka Tanah Negara Dalam Wilayah Kabupaten } \\
\text { Kutai Kartanegara }\end{array}$ & 2017 \\
\hline 8 & $\begin{array}{l}\text { Peran Serta Lokal Terhadap Ekstraktif Migas } \\
\text { DPRD Angan Dan Aministratif Pimpinan Dan Angota }\end{array}$ & 2017 \\
\hline 10 & $\begin{array}{l}\text { Pembentukan Perseroan Daerah Mahakam Gerbang Raja } \\
\text { Migas }\end{array}$ & 2017 \\
\hline 11 & $\begin{array}{l}\text { Pencegahan dan Peningkatan Kualitas Terhadap Perumahan } \\
\text { dan Permukiman Kumuh. }\end{array}$ & 2018 \\
\hline 12 & $\begin{array}{l}\text { Perubahan Atas Peraturan Daerah Nomor 12 Tahun 2017 } \\
\text { Tentang Pembentukan BUMD PT.MGRM. }\end{array}$ & 2018 \\
\hline
\end{tabular}

Sumber: Bapemperda DPRD Kutai Kartanegara Tahun 2019

Faktor yang mempengaruhi peran DPRD dalam melaksanakan fungsi pembentukan perda yang pertama adalah sumber daya manusia. Alat ukur yang paling banyak digunakan dalam melihat kualitas sumber daya manusia adalah tingkat pendidikan. Berdasarkan data tingkat pendidikan di DPRD Kutai Kartanegara sudah cukup baik, karena hanya 10 anggota DPRD dengan tingkat pendidikan SLTA. Untuk mengatasi masalah yang disebabkan oleh faktor pendidikan, DPRD didampingi oleh tim ahli dan staf sekretariat DPRD dalam hal 
melaksanaan fungsi pembentukan peraturan daerah; sehingga pada dasarnya tingkat pendidikan tidak lagi banyak berpengaruh terhadap peran DPRD dalam pelaksanaan fungsi pembentukan peraturan daerah.

Faktor yang kedua adalah pengalaman. Alat ukur yang digunakan untuk melihat pengalaman disini adalah lamanya menjabat sebagai anggota DPRD yang dilihat dari periodeisasi keanggota dan pengalaman organisasi lainnya. Berdasarkan data mayoritas anggota DPRD periode 2014-2018 adalah anggota baru, meskipun demikian tahun ini (2019) sudah memasuki tahun ke-lima keanggotaan, artinya anggota DPRD tersebut telah menjabat lebih dari 4 tahun. Sedangkan yang berkaitan dengan pengalaman organisasi, mayoritas anggota DPRD memiliki pengalaman organisasi, karena memiliki jabatan struktural di partai atau organisasi sayap partai lainnya. Untuk mengatasi masalah pengalaman, selain didampingi oleh Tim Ahli, anggota DPRD juga mendapatkan hak untuk mengikuti workshop atau pelatihan dalam rangkan meningkatkan kapasitas yang difasilitasi oleh Sekretariat DPRD setiap masa sidang atau 4 bulan sekali. Pelaksanaan workshop sendiri diadakan sesuai dengan kebutuhan dan usulan alat kelengkapan DPRD.

Faktor yang ketiga adalah dukungan data dan informasi. Data dan informasi merupakan hal yang sangat diperlukan oleh DPRD dalam melaksanakan fungsi pembentukan perda. Data dan informasi tersebut dapat disediakan oleh Tim Ahli DPRD. Dalam hal pembentukan perda, data dan informasi tersebut telah disajikan dalam bentuk naskah akademik yang merupakan dokumen wajib sebagai kelengkapan dari rancangan perda yang diusulkan.

Oleh karena itu, teori yang dikemukakan oleh Prawirosentono yang menyebutkan tiga faktor yang mempengaruhi peranan suatu organisasi dalam melaksanakan tugas dan fungsinya yaitu faktor pendidikan, pengalaman dan faktor data/ informasi telah ditanggulangi sebelumnya sehingga tidak lagi menjadi faktor penghambat. Justru faktor yang paling banyak berpengaruh terhadap peran DPRD dalam pembentukan perda adalah faktor politis, karena anggota DPRD berasal dari partai politik yang beragam. Hal ini dibuktikan dengan adanya beberapa kali penundaan paripurna pengesahan rancangan perda menjadi perda akibat belum adanya kesepahaman antara DPRD dan 
Pemerintah Daerah. Faktor penghambat lainnya adalah ketidak-konsistenan regulasi yang mengatur pembentukan perda. Dalam Permendagri 80 Tahun 2015, disebutkan bahwa Propemperda merupakan pedoman dalam penyampaian usulan rancangan perda. Tetapi kemudian didalam Pasal 16 ayat (5) Permendagri 80 Tahun 2015, tetap diberikan ruang pengajuan rancangan perda diluar propemperda yang telah disepakati. Hal ini menyebabkan hasil pembahasan dan kesepakatan propemperda menjadi siasia. Selain itu juga menyebabkan terjadinya pembengkak-kan anggaran, karena bertambahnya rancangan perda yang akan dilakukan pembahasan. Kalau kemudian anggaran tidak mendukung untuk pembahasan rancangan perda penambahan, maka akan mengorbankan rancangan perda yang telah menjadi prioritas dalam propemperda.

Ketidak-konsistenan regulasi ini juga berkaitan dengan adanya kewajiban mendapatkan nomor register dari Biro Hukum Propinsi terhadap perda yang telah disahkan. Di dalam Pasal 100 ayat (2) Permendagri 80 Tahun 2015 disebutkan bahwa Bupati wajib menyampaikan rancangan perda yang telah disahkan kepada Gubernur sebagai wakil pemerintah pusat untuk dilakukan evaluasi atau mendapatkan nomor register. Adanya kewajiban ini menghambat peran DPRD dalam melaksanakan fungsi pembentukan perda, karena perda yang telah disahkan tidak dapat di undangkan dalam lembaran daerah sebelum mendapatkan nomor register. Dampaknya perda yang telah melalui proses pembahasan yang panjang sampai dengan disahkan tetap tidak bisa dilaksanakan karena belum diundangkan dalam lembaran daerah. Masih rendahnya kinerja DPRD periode 2014-2018 dalam pembentukan peraturan daerah lebih lagi dalam pelaksanaan hak inisiatif DPRD juga disebabkan oleh terlalu banyaknya rancangan perda dalam propemperda (target) yang akan dilakukan pembahasan dimana rata-rata mencapai 30 rancangan perda per tahun. Padahal keanggotaan DPRD hanya 45 orang atau maksimal 4 pansus pada setiap masa sidang. Sehingga idealnya setiap tahun hanya 16 rancangan perda yang bisa dilakukan pembahasan dan disahkan.

\section{SIMPULAN}

Berdasarkan hasil penelitian dapat disimpulkan bahwa DPRD Kutai Kartanegara berperan dalam melaksanakan fungsi pembentukan peraturan daerah, walaupun belum 
optimal dalam pelaksanaan hak inisiatif karena rata-rata hanya $8,05 \%$ yang disahkan menjadi perda. Faktor pendidikan, pengalaman dan faktor dukungan data/ informasi, berpengaruh terhadap peran DPRD dalam melaksanakan fungsi pembentukan perda, hanya saja tidak lagi menjadi faktor penghambat karena telah diatasi dengan adanya Tim Ahli/ Kelompok Pakar, adanya workshop atau pelatihan untuk meningkatkan kapasitas DPRD dan adanya naskah akademik dalam setiap rancangan perda yang diajukan ke DPRD. Faktor penghambat dari peran DPRD dalam pelaksaaan fungsi pembentukan peraturan daerah adalah faktor politis, dukungan anggaran dan konsistensi regulasi. Masih rendahnya kinerja DPRD periode 2014-2018 dalam pembentukan peraturan daerah lebih lagi dalam pelaksanaan hak inisiatif DPRD juga disebabkan oleh terlalu banyaknya rancangan perda dalam propemperda (target) yang akan dilakukan pembahasan dimana rata-rata mencapai 30 rancangan perda per tahun. Padahal keanggotaan DPRD hanya 45 orang atau maksimal 4 pansus pada setiap masa sidang. Sehingga idealnya setiap tahun hanya 16 rancangan perda yang bisa dilakukan pembahasan dan disahkan.

\section{UCAPAN TERIMA KASIH}

Ucapan terima kasih kepada Pimpinan DPRD yang telah memberikan ruang bagi penelitian tentang evaluasi kinerja DPRD khususnya yang berkaitan dengan fungsi pembentukan Peraturan Daerah.

\section{DAFTAR PUSTAKA}

Abidin, S. Z. 2006. Kebijakan Publik. Jakarta: Suara Bebas.

Jusmiati. 2013. Pelaksanaan Fungsi Legislasi DPRD Kabupaten Kutai Timur. Ilmu Pemerintahan Fisip Universitas Mulwarman, Nomor 1 Volume 5, hal. 1704-1715.

Keban, Y. T. 2015. Enam Dimensi Administrasi Publik, konsep teori dan isu. Yogyakarta: Gava Media.

Kurniadi, T. 2013. Pelaksanaan Fungsi Legislasi DPRD Propinsi Kalimantan Barat. Jurnal Tesis PMIS-UNTANPSIP-2013, hal. 1-18.

Manan, B. 1994. Hubungan Pusat dan Daerah Menurut UUD 1945. Jakarta: Sinar Harapan.

Prawirosentono, S. 2002. Kebijakan Kinerja Karyawan: Kiat Membangun Organisasi Kompetitif Menjelang Perdagangan Bebas Dunia. Yogyakarta: BPFE.

Sanit, A. 2012. Sistem Politik Indonesia. Jakarta: Rajawali Press. 
NATAPRAJA Vol. 7, No. 1, 2019

Suharto, E. 2009. Kemiskinan \& Perlindungan Sosial di Indonesia.

Bandung: Alfabeta.

Winarno, B. 2007. Kebijakan Publik:

Teori dan Proses. Yogyakarta:

Media Pressindo. 